\title{
Boletín de la Sociedad Geológica Mexicana
}

VOLUMEN 66, NÚM. 1, 2014, P. 53-63

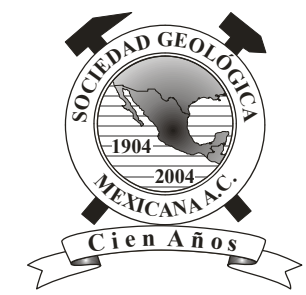

\section{Assembling extinct plants from their isolated parts}

\author{
Steven R. Manchester ${ }^{1, *}$, Laura Calvillo-Canadell'2, Sergio R.S. Cevallos-Ferriz ${ }^{2}$ \\ ${ }^{1} 214$ Florida Museum of Natural History, Dickinson Hall, Museum Road \& Newell Drive, Gainesville, FL 32611 \\ ${ }^{2}$ Instituto de Geología, UNAM; Ciudad Universitaria, Circuito de la Investigación Científica, Copilco el Alto, Coyoacan; 04510; \\ México D.F. \\ *steven@flimnh.ufl.edu
}

\begin{abstract}
Fossils have always been an intriguing and spectacular source of information for naturalists who discuss how life and diversity came about. In plants, it is difficult to find in the fossil record all organs or plant parts in connection to each other. Thus, many angiosperms are sketched as undefined entities that somehow resemble an extant relative. Nevertheless, several examples of whole plant reconstructions based on extensive collection of fossil parts have been published through the years. Two methods have been used to reconstruct fossil plants: 1) Through organic connections among the different organs, and 2) concurrent location of fossil parts (seed, leaves, flowers, etc.) in the same locality and across localities. In the latter case, the argument can be strengthened by similarities of epidermal anatomy. The association of organs gives a more complete picture of fossils plants and it can help to make better taxonomic inferences, as they provide a morphological tool about plants that grew in the past. This information may as well be used in other areas, such as biogeography or phylogenetics.
\end{abstract}

Keywords: Fossil plants, organic connection, reconstruction, morphological tool, association.

\section{Resumen}

Los fósiles han sido siempre una fuente de información fascinante y espectacular para los naturalistas que hablan de cómo se produjo la vida y la diversidad. En el registro fósil de plantas es dificil encontrar todos sus partes u órganos relacionados entre sí, por lo que muchas angiospermas se esbozan como entidades no definidas que de alguna manera asemejan a un pariente actual. Sin embargo, existen numerosos ejemplos de reconstrucción de plantas publicados a través de los años y que se han basado en una amplia colección de piezas fósiles. Existen dos métodos para reconstruir a las plantas: 1) Mediante la conexión orgánica entre los diferentes órganos, y 2) la concurrencia de partes fósiles (semilla, fósiles, hojas, etc.) en la misma localidad y entre localidades. En este último caso, el argumento puede ser reforzado por las similitudes en la anatomía de la epidermis. La asociación de órganos permite crear imágenes de plantas fósiles más completas y puede ayudar a realizar mejores inferencias taxonómicas, ya que proporcionan una herramienta morfológica acerca de las plantas que crecieron en el pasado. Esto puede aportar información en otras áreas como la biogeografia o la filogenia.

Palabras clave: Plantas fósiles, conexión orgánica, reconstrucción, herramienta morfológica, asociación. 


\section{Introduction}

Fossils have always been an intriguing and spectacular source of information; for naturalists who discuss how life and diversity came about, for literacies who write fantastic histories on giants and lost worlds, and even for artists who depict spectacular scenes of past life in painting canvas, dioramas in museums, newspapers or TV cartoons. While in general the image of a long extinct animal is portrayed with great detail, plants, however, are sketched as undefined entities that somehow resemble an extant relative. This difference in the representation of the organisms may be explained with the understanding of their life history. Animals throughout their lives have their parts assembled as a whole.That is, they do not lose an arm in winter, or their eyes during the summer, and when they die their parts usually remain together (unless scavenged by other animals). In contrast, many angiosperms, for example, produce leaves and flowers in the spring, flowers mature into fruits in the summer, and leaves and other organs tend to abscise annually. Thus, it is difficult to find in the fossil record all organs or plant parts in connection to each other. This is the reason why most paleobotanists collect only isolated pieces, with certain exceptions to this general idea. It is possible to find disarticulated bones or exuviae of invertebrates; but it is most likely to find articulated specimens close to the isolated remains that help generate a more complete idea on the phenotype of the organism. While in animals there is usually a size correlation between organ and animal, so much that the rule is used to estimate body sizes and create reconstructions of extinct animals, such correlation does not exist in plants. Nevertheless, numerous examples of whole plant reconstruction based on extensive collection of fossil parts have been published throughout the years; and the picture of past plants has become more complete and appropriate for other areas, such as biogeography or phylogenetics.

\subsection{Methods to reconstruct plants}

Two methods have been used to reconstruct plants: 1) Through organic connections among the different organs; this is the most spectacular and it is widely accepted, and 2) common occurrence of organs in more than one locality where a single plant organ of a particular group is present, suggesting that the particular organs belong together. In the latter case the argument can be strengthened by similarities of epidermal anatomy.

Two of the most significant examples of plant reconstruction lead to the recognition of Pteridosperms and Progymnosperms, both from the Upper Paleozoic. The abundance of fern and fern-like leaves in Devonian and Carboniferous rocks suggested that Pteridophytes were extremely important at that time, but the discovery of organs in organic connection demonstrated the presence of plant groups that were not even hypothesized at that time. Their recognition changed dramatically our understanding of diversity, plant evolution, and the relationships among plant groups. While Pteridosperms were plants that had stems with eusteles, naked seeds like the maidenhair tree (Ginkgo biloba), secondary growth, and frond-like leaves like ferns, Progymnosperms reproduced through spores like ferns, but their wood was more similar to that of conifers.

Understanding other Mesozoic groups has been equally challenging. However, the process of assembling different plant organs also allowed the recognition of several distinct groups sometimes included in the concept of Mesozoic Pteridosperms. This is the case of the Glossopteridales, Caytoniales, Corystospermales, Peltaspermales, Bennetitales or Pentoxylales. All these groups further contributed to expand our understanding of past plant diversity and have been widely used to propose different relationships among group of plants, including angiosperms.

In more recent decades, building up a concept of the first flowering plant has remained a challenge, and the exchange of ideas is still a dynamic part of the discussion of the first angiosperms. The relatively recent recovery of plants with many organs connected has animated this discussion, where the same specimens representing a whole plant inspired contrasting ideas or hypothesis.

In the next pages we will expose some examples of organs that have been reconstructed into a single plant, and explain some aspects of plant biology that highlight the importance of assembling whole plants to further understand different aspects of plant systematics.

The present contribution expands on a lecture delivered by SRM during the IOPC-Bonn based on wide bibliographic review and ongoing research. The examples to discuss include Aesculus hickeyi sp. nov., Syzygoides americana (Lesq.) Manchester, Dilcher et Wing (Manchester et al., 1998), Ulmus okanogensis Denk \& Dillhoff, Populus tidwellii sp. nov., Pseudosalix handleyi Boucher, Manchester et Judd, Polemoniaceous plant, Fagopsis longifolia (Lesq.) Hollick, Cedrelospermum Saporta, Florissantia quilchenensis Manchester; Limnobiophyllum scutatum Stockey, Hoffman \& Rothwell, Archaefructus liaoningensis Sun, Dilcher, Zheeng et Zhou and A. sinensis sp. nov., Archaeanthus Dilcher \& Crane, Polypteramanningii Manch. et Dilcher, Juglandiphyllites glabra (Brown ex Watt) Manch. et Dilcher, Nordenskioeldia Heer, Beringiaphyllum cupanioides (Newb.) Manch., Crane \& Golovneva, Amersinia obtrullata Manch., Crane et Golovneva, Davidia antiqua (Newberry) Manch. and Camptotheca, Macginitiea, Macginicarpa Manchester. We include some comments on the co-occurrence of vegetative and reproductive organs in some Mexican localities that may represent a single plant, and whose recognition would have important biogeographic consequences. 


\section{Discussion}

\subsection{Leaves}

One of the most difficult aspects of plant taxonomic determinations based on leaf characters is determining if the fossil represents a leaf or a leaflet. Examples of isolated fossil leaf/leaflets that have been suggested to represent different taxa are well known, but we will exemplify this situation with a couple of extinct plants. Collecting leaves with myrtaceous characters in Cenozoic sediments in North America is common, but demonstrating that they actually belong to this family is a difficult task (Lesquereux, 1872, 1878; MacGinitie, 1969; Pigg et al., 1992). In Paleogene sediments of North America, leaves with leaf architecture resembling that of Myrtaceae have been compared with leaves of Eucalyptus, Eugenia, Calyptranthes, Myrcia and even Syzygium. However, due to convergent evolution in leaf architecture among different clades of the family, their exact taxonomic position remains uncertain unless other organs are present. Samples with fossil material housed at the Buffalo Museum of Science, New York (BMS), Cornell University, Ithaca (CUPC), University of Colorado Museum (UCM), the U.S. National Museum, Washington, D.C. (USNM), and the Denver Museum of Natural History (DMNH) were examined by Manchester et al., (1998), along with specimens including branches with attached leaves and fruits preserved in the shales of the Green River Formation from localities near Douglas Pass, Colorado (Figure 1). They confirmed the myrtaceous affinity of the isolated leaves, and noted a closer affinity of the fossil leaves with those of Syzygium. Because at least one sample had fruits attached to a twig with Syzygium-like leaves, they were able to demonstrate that the reproductive structures were different from those expected for Eucalyptus (to which the species had first been assigned) and for Syzygium, and thus, the assignment of the fossil material to this genus was incorrect. The presence of an extinct taxon was then recognized, highlighting the need to refrain from including isolated leaves with myrtaceous affinity to this family if reproductive structures cannot be associated.

Aesculus hickey Manchester (Sapindaceae; Figure 2) further exemplifies the problems encountered when identifying isolated leaf/leaflets. While this species had been frequently reported from Cenozoic deposits of the Northern Hemisphere (Brown, 1962; Hickey, 1977), leaves with similar leaf architecture were suggested to represent members of Carya (Juglandaceae) (Newberry, 1868, 1898; Brown, 1962; Hickey, 1977). Material from the Fort Union Formation, North Dakota, including leaflets, complete compound leaves, and fruits demonstrated that a plant with palmately compound leaves with 3-5 petiolated leaflets and non-glandular teeth, as well as trivalved globular capsules with external spines, actually represents a member of Aesculus. The confirmation that these organs belong to a single plant type finally confirmed the presence of this genus in North America during the Paleogene. At the same time, it highlighted the importance to be cautious if juglandaceous material is found in the same locality, since other material referred to Carya seems to actually represent a member of this family, though not necessarily this genus. The presence of these two taxa in the Paleogene is further supported by the presence in sediments of pollen grains referred to Aesculus-like pollen and Momipites. They both document the presence of extinct taxa that were otherwise thought to be more closely related to different extant taxa; their recognition added important data to discuss their systematic position and geographic origin (Manchester, 2001).

Relatively recent studies on Ulmus described a common situation found in plant systematics. The taxonomic position of Ulmaceae was thought to be closer to Urticales, but now it is placed within Rosales. The fossil record of Ulmus in western North America based on leaves and fruits helped to understand part of the uncertainties when defining this group (MacGinitie, 1941, Burnham, 1986; Manchester, 1989a, 1989b; Denk and Dillhoff, 2005). Twigs with attached and well-preserved leaves, flowers, fruits and isolated organs from the Early and Middle Eocene of Washington and British Columbia, allowed the recognition of Ulmus okanaganensis Denk and Dillhoff (Figure 3; Denk and Dillhoff, 2005). The physical attachments gave vital proof of interconnection between foliage and reproductive structures, providing the highest level of confidence on the construction of a single plant. In addition, as in the case of other similar discoveries, it also revealed unexpected character combinations. Similar to previous examples, the reconstructed plant turned out to represent an extinct taxon with a unique mosaic of characters, expanding our idea of the diversity of this genus. The leaf dimorphism found in $U$. okanagansis is similar to that seen in extant $U$. pumila, while reproductive structures comprise a mosaic of characters found in the subgenera Oreoptelea or Ulmus. Older and younger leaves similar to those of U. okanagansis have been reported from other localities in Europe and North America (e.g., Ablaev and Iljinskaja, 1982; Manchester, 1989a, 1989b; Kvaček et al., 1984; McIver and Basinger, 1999; Feng et al., 2003), but in absence of reproductive material, especially fruits, it is difficult to determine correctly their taxonomic position. The reconstruction of this fossil plant highlights the importance of whole plant concepts that can further contribute to taxonomy and biogeography.

\subsection{Other isolated organs}

As with most plant families, there are more examples of isolated organs in the fossil record of Ulmaceae where samples with different organs attached to the same axes complements our understanding of the fossil material as a biological entity. The study of the parts is important to demonstrate the presence of past life, but reconstructing the organisms allows a better understanding of different 
aspects of their biology.

The Cedrelospermum case illustrates this situation. Prior to finding samples in the Green River Formation showing leaf and fruits attached to the same twig (Figure 8), isolated leaves were referred to as Myrcia (Myrtaceae), Salix (Salicaceae) and Zelkova (Ulmaceae); (Brown, 1946; MacGinitie, 1953, 1969, 1974; Burnham, 1986). Tanai and Wolfe (1977) were the first authors to treat them as Ulmaceae, and noted that these leaves were not similar to those of the extant plants. Later, Burnham (1986) compared this fossil material to Zelkova, but also mentioned that it represented a different morphotype within this genus. Manchester (1989a, 1989b) was able to demonstrate which flowers, fruits, leaves, and pollen grains were part of Cedrelospermum, and reassembled a new plant that he related to Ulmoideae. He further suggested that Cedrelospermum (the genus erected by Saporta based on the same kind of fruits from the Cenozoic of France) differentiated during the same radiation process that gave rise to Ulmus and Zelkova. Apparently Cedrelospermum had a widespread distribution during the Paleogene in the Northern Hemisphere. Its presence is associated with localities where ash accumulated in lacustrine conditions, suggesting that it represents an early colonizer of disturbed areas, a condition that may be comparable with the ecological tolerance of some members of Celtidoideae, Trema and Parasponia (Soepadmo, 1977).

Poplars (Populus) and willows (Salix) are other important components of the Paleogene floras of Northwestern North America; understanding their history is relevant to further understand the inclusion of some of the former flacourtiaceous taxa in this group (Chase et al., 2002; Judd et al., 2002; Boucher et al., 2003; Soltis et al., 2005). Representatives of both genera have been recognized for a long time, but their organs were always isolated (Knowlton, 1923; Cockerell, 1925; Brown, 1929, 1934; MacGinitie, 1969). It was not until remarkable materials with leaves and reproductive structures were recently collected, allowing a better interpretation of the fossil plants (Figures 4 and 5; Boucher et al., 2003; Manchester et al., 2006). The recent discovery of lanceolate fossil leaves similar to those of $P$. cinnamomoides attached to a twig bearing fruits morphologically distinct from those of $P$. wilmattae proves that there were at least two distinct species (P.tidwellii and P. wilmattae) in this geographic area, and encouraged a broader investigation of Populus species represented in the Eocene of western North America (Manchester et al., 2006). From a phylogenetic perspective, P. tidwellii must either be a member of the Populus clade or, like Pseudosalix, an early divergent member of the clade containing Populus and Salix that is characterized by the Populus-type capsule (Boucher et al., 2003; Manchester et al., 2006). These investigations forewarn of evaluating fossil leaves that are not clearly associated with informative inflorescences or infructescences. The recognition of these taxa is also biogeographically important since it supports the possibility that Salicaceae had a North American origin since its outgroups (Itoa, Poliothyrsis, Carriera and Idesia) have today an Asiatic distribution (Boucher et al., 2003).

\subsection{Biogeography and phylogenetic}

An interesting plant known from complete specimens material including vegetative and reproductive parts-the taproot, basal and cauline pinnatifid leaves, primary peduncular leaves, secondary peduncular bracts, pedicel bracts, fruits in groups of three, and persistent calyx-allowed the documentation of a herb that grew during the Middle Eocene in Utah and was preserved in the sediments of the Green River Formation (Lott et al., 1998). Though fossilization of an entire plant is rare, the preservation quality of some characters like the presence of a calyx with membranous tissues between the ribs, the pollen and the trichomes, prevented its inclusion in Gilia (Polemoniaceae). As a result, a new taxon-Gilisenium huberi Lott, Manchester and Dilcher (Lott et al., 1998) (Figure 6)-was erected. Polemoniaceae has a relatively poor fossil record and the documentation of a plant that is undisputedly a member of the family expanded its distribution in time and space. Furthermore, its early appearance in North America and close morphological similarity to Gilia could suggest that the tribe originated in this area and only later moved to South America (Lott et al., 2003).

Samples of plant organs displaying alternately arranged simple leaves with pinnate craspedodromous venation, prominent simple teeth, stout peduncle topped with a staminate globose infloresences, tricolporate pollen contained in anthers, ovoid heads of pistillated inflorescences with compact helically arranged trimerous flowers, and small infructescences subtended by a persistent bract and with wedge-shaped cupules, each containing three tiny fruits, have all been linked to a single plant: Fagopsis longifolia (Lesq.) Hollick (Figure7). While all these characters support the assignment of the plant to Fagaceae, the mosaic of characters is not found in any extant taxon, supporting again the recognition of a new one. Furthermore, differences between extant and extinct plants go beyond the morphology of the plant; the fruits of the fossil plant seem to be adapted for wind dispersion, while extant members of the family disperse fruits through animal interaction. The evident difference in fruit morphology somehow supports the change in dispersal method, a situation that may be parallel if extinct and extant Juglandaceae and Betulaceae taxa are compared (Hollick, 1909, Manchester and Crane, 1983).

\subsection{Co-ocurrence}

Organs of aquatic plants have been recognized in the fossil record for a long time and some of them have been reconstructed as whole plants. However, these reconstructions have not always been widely accepted (McIver and Basinger, 1993; Kvaček, 1995). 

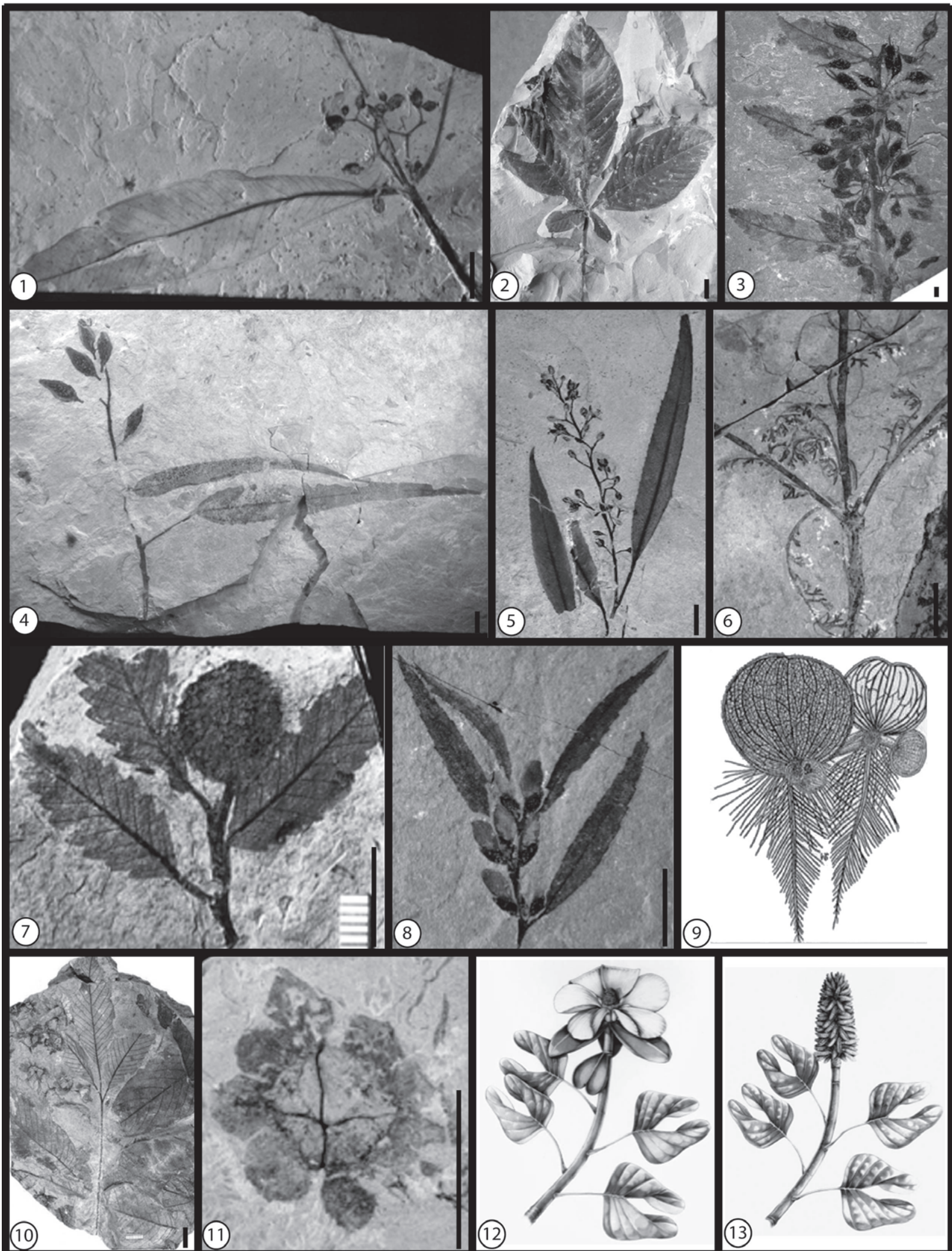

Figure 1) Syzygioides americana(Lesq. x) Manchester, Dilcher et Wing. 2) Aesculushickeyi Manchester. 3) Ulmus okanogensis Denk \& Dillhoff. 4) Populus tidwellii Manchester, Judd \& Handley. 5) Pseudosalix handleyi Boucher, Manchester \& Judd. 6) Gilisenium huberi Lott, Manchester and Dilcher. 7) Fagopsis longifolia (Lesq.) Hollick. 8) Cedrelospermus nervosum (Newberry) Manchester. 9) Reconstruction of Limnobiophyllum scutatum (Dawson) Krassilov. Scale $5.2 \mathrm{~cm}$. 10) Juglandiphyllitesglabra (Brown ex Watt) Manchester et Dilcher. 11) Polypteramanningii Manchester et Dilcher. 12) Archaeanthus Dilcher \& Crane 1984 Cretaceous of Kansas, flower. 13) Archaeanthus Dilcher \& Crane 1984 Cretaceous of Kansas, infrutescence. 
Limnobiophyllum scutatum (Dawson) Krassilov, from the Paskapoo Formation near Red Deer (Jofree Bridge), Alberta, Canada (Figure 9), is a well-known floating flowering plant whose detailed description allowed its inclusion in numerical analyses that suggested that Lemnaceae and Pistia were monophyletic within Araceae (Stockey et al., 1997). The environment where this plant grew is compared with those where extant Lemnaceae grow (Stockey et al., 1997), associated with other aquatic plants like Riccia and Azolla (Landolt, 1986). Hoffmann (1995) described from these same sediments a thallus of a Riccia-like plant living as she described in an oxbow lake.

The co-occurrence of organs that could represent the same taxon is frequently used to propose that they actually correspond with a single plant type, especially if there are no other organs to which they could be attributed. Polypteramanningii Manch. et Dilcher and Juglandiphyllitesglabra (Brown ex Watt) Manch. et Dilcher are good examples of this condition (Figures 10-11). Both of them can be compared with fruits or leaves of Juglandaceae, and no other plant organ (infructescences, fruits, staminate catkins, pollen, compound leaves) with Juglandaceae affinity is known in the localities where they co-occur. Their co-occurrence in at least 10 localities of the Paleocene Fort Union Formation, Wyoming, is a useful criterion to propose their association. However, the taxonomic affinity (Hicorieae and Juglandeae) suggested for the different organs was also important to support their binding into a single plant. This reconstructed plant represents the oldest unequivocal record of Juglandaceae. The use of fossil plants in phylogenetic analysis has been discussed both in favor and against (Manos et al., 2007). In a phylogenetic study of Juglandaceae the positions of extant taxa relative to each other was not radically changed when the fossils were included (Manos et al., 2007). After a combined molecular and morphological analysis, Manos et al. (2007) concluded that "the inclusion of morphological characters, scored for both extant and fossil taxa, may improve the results of both morphological and combined morphomolecular investigations, particularly if this increases the number of synapomorphies. In general, reproductive characters proved more informative than vegetative characters for Juglandaceae. However, the greatest resolution came from taxa known from combined vegetative and reproductive organs, arguing in favor of assembling extinct taxa through multiple-organ reconstructions in order to maximize the number of characters included in the matrices."

The recognition of Archaeanthus linnenbergeri Dilcher and Crane in 1984 (Figures 12-13), based on the presence of distinctive resin bodies and co-occurrence of organs in various localities, represents one of the earliest angiosperms subject to the assemblage of its parts. Its isolated parts were known previously as Archaepetala beekeri Dilcher and Crane and Archaepetala obscura Dilcher and Crane (perianth parts), Kalymmanthus walkeri Dilcher and Crane (bud scales), and Liriophyllum kansense Dilcher and Crane (leaves). This whole plant assemblage is based on three main sources of evidence: co-occurrence, anatomical similarities, and taxonomic affinities.

Another example of whole plant reconstruction is the "Nordenskioldia plant" based on the co-occurrence of Nordenskioldia borealis Heer emend. Crane, Manchester and Dilcher, and Zizyphoides flabella (Newberry) Crane, Manchester, and Dilcher (Crane et al., 1991; Figures 1416). The isolated organs of these plants were collected for many years in at least 9 localities. Their association varies from rare to abundant and common. The comparison of the floras at Almont, Melville, and Monarch with those at other Paleogene localities in Asia, Europe, and North America provides evidence of associations supporting earlier conclusions that the Nordenskioeldia plant bore simple, entire- to crenate- margined leaves with actinodromous venation. The morphological and anatomical characters available supported the placement of the new plant within Trochodendrales as an extinct genus close to Trochodendron (Crane et al., 1991). Nordenskioldia is defined by the presence of virtually entire-margined leaves with long petioles, single-seeded dehiscent fruitlets, seeds with an elliptical outline, infructescence structure, and several anatomical details of infructescence axes and shoots, characters not found in other members of Trochodendrales, (Crane et al., 1991). These differences highlight the importance of comparative biology in systematics. Other differences suggest the possibility that insect pollination was less specialized in Nordenskioeldia than in extant Trochodendron (Endress, 1989); even the possibility of wind pollination cannot be excluded, as suggested by the absence of nectary scars on Nordenskioeldia fruitlets.

A fourth example of a plant reassembled from its dispersed parts is a taxon within Corneales. Dispersed organs of this plant have been collected in middle and high latitudes of the Northern Hemisphere; the Paleocene of Wyoming, Montana and North Dakota, USA; Alberta, Canada; Heilongjiang, China; and Kamchatka and Koryak, Russia. Infrutescences, fruits, and leaves co-occur in these areas and were previously identified as similar to extant Camptotheca, genus distinguished by having fruits with only one or two locules and not presenting infructescence bracts. The fossil leaves were initially referred to as "Viburnum" cupanioides (Newberry) Brown, Viburnum kingiensis Chelebaeva, and Viburnum pseudoantiquum Golovneva, but later were reassigned to an extinct foliage genus, Beringiaphyllum. The reconstructed plant was named Amersinia obtrullata Manchester, Crane and Golovnea based on shared cornalean characters and co-occurrence at numerous sites mentioned above (Figures 17-19). However, while leaves share more characters with Davidia, the fruits are more similar to Camptotheca. The new plant as in the previous examples is a defined extinct taxon and not just an earlier relative of an extant taxon. 


\subsection{Plants preserved as whole organisms}

The presence of plants preserved as whole organisms with roots, stems, leaves and reproductive structures, all in organic connection in the fossil record is rare (Figure 20). Archaefructus is a good example in which not only one plant type, but at least three different species have been described. These early angiosperms have been interpreted as representing an ancestral group to modern angiosperms, a derived eudicot, or even a plant related to Nymphaeales. This demonstrates that even knowing whole plants it is difficult to achieve unambiguous answers. Archeofructus has been compared to other Mesozoic plants like Caytonia (Zhou et al., 2003), Dirhopalostachys (Krassilov, 1975) and Schweitzeria (Irania) (Schweitzer, 1977; Shipunov and Sokoloff, 2003). There are other interesting reports of very complete plants from Cretaceous sediments that have added important information to the history of angiosperms (see Friis et al., 2011), but none of these has solved many questions regarding angiosperm origin and its early diversification.

Probably one of the groups with an overwhelming fossil record of complete plants assembled from their dispersed organs is Platanaceae (e.g., Manchester, 1986; Pigg and Stockey, 1991). The isolated organs have been collected from different localities in the Northern Hemisphere; they include leaves (e.g, Platanites), staminate inflorescences (e.g., Platanathus, Aquia, Bogutchanthus?), pistilate inflorescences (e.g., Macginicarpa, Platanocarpus), wood (e.g., Plataninium, Platanoxylon, Spiroplatanoxylon), and pollen taxa (e.g., Friis et al., 1988; Pedresen et al., 1994; Magallón-Puebla et al., 1997; Manchester, 1986; Pigg and Stockey, 1991; Kvaček et al., 2001; Kvaček and Manchester, 2004; Mindell et al., 2006; Golovneva, 2008). Recently, Maslova (2008) made a review of the association of leaves and reproductive structures with platanoid affinity, and discussed their possible phylogenetic implications. Morphological observations of vegetative and reproductive organs of Cretaceous age suggest that the platanoid pattern was widely distributed. This can be explained by either a high diversity of platanoid plants or the presence of different linages with platanoid-like characters (Maslova, 2008). For example, the Angiosperm Phylogeny Group (2009), places platanoid plants in Proteales and hamamelidoid plants in Saxifragales and they both present platanoid characters. However, most authors agree on the high diversity of platanoid plants during the Cretaceous (Figures 21-22). The recognition of a significant number of platanoid plants during the Cenozoic further corroborates the extent of the diversity that this family achieved in the past, and how it later diminished to the point that today it is represented only by a couple of species. The delimitation of the fossil and extant species is still a matter of interesting discussion, but as a whole the Platanaceae represents a group that highlights the importance of reassembling isolated organs into organisms. This emphasizes how discussion on taxa limits becomes relevant and equivalent to the information produced through the study of extant plants (Manchester, 1986; Friis et al., 1988; Crane et al., 1989, 1993; Pigg and Stockey, 1991; Magallón-Puebla et al., 1997).

Kvaček (2008) recently commented on whole plant reconstructions of fossil angiosperms using some of the examples we mentioned above, but he also added other important examples. His discussion of Malvaceae, for example, stresses how fossil and extant plants of this family are equally variable in leaf characters, but are more constant in fruit morphology. He further emphasizes the importance of connection between organs, since in the localities where these organs co-occur, malvaceous wood types are more diverse. This suggests that at least another malvaceous plant may be present, and thus more work is needed to complete these plant reconstructions. A second example cited by Kvaček (2008) is Nyssa, in particular N. bilinica (Ung.) Kvaček. Shade and sun leaves associated with fleshy fruits and isolated stones have been documented for this plant. The leaves are similar to the $N$. japonica complex while the fruits resemble the $N$. sylvatica- $N$. sinensis complex. The inflorescences collected in the same sediments have characteristics of both complexes. Therefore, the Nyssa remains of the Bilina Mine, Central Europe, represent an extinct taxon with a mosaic of characters found today in different taxa.

A final example is the documentation of Trichosanthes (Cucurbitaceae) in the Pliocene flora of Alsace, France. Here, leaves morphologically similar to Acer were demonstrated to have stomatal apparatuses, glands, and pubescence that do not correspond with this genus. Among the fruits collected in this locality is a type assigned to Trichosanthes fragilis E.M. Reid (Cucurbitaceae) that has palmately lobed leaves. The anatomical and morphological characters were used to support the similarity of this leaf type to this genus, which grows naturally today in Asia and Australia. However, the presence of seeds assigned to Cucurbitaceae, yet distinct to those of Trichosanthes, prevents the inclusion of the fossil in this genus.

\subsection{Reconstruction of fossil plants of Mexico}

Finally, the presence of at least two different organs of the same taxon in some localities in Mexico can be used to suggest that extinct species of some genera were present in this geographic area since at least the Middle Eocene. Certainly more data are needed to further support these determinations, but evidence so far seems strong to anticipate the presence of taxa that otherwise were expected to arrive to the area, as the so-called "Neotropical flora" expanded to Mexico. In fact, the presence of these "Neotropical taxa" suggests that the history of this flora may be more complex than previously expected. An earlier whole plant documented from Sonora, Mexico, includes an Upper Cretaceous Haloragaceae described by Hernández- 


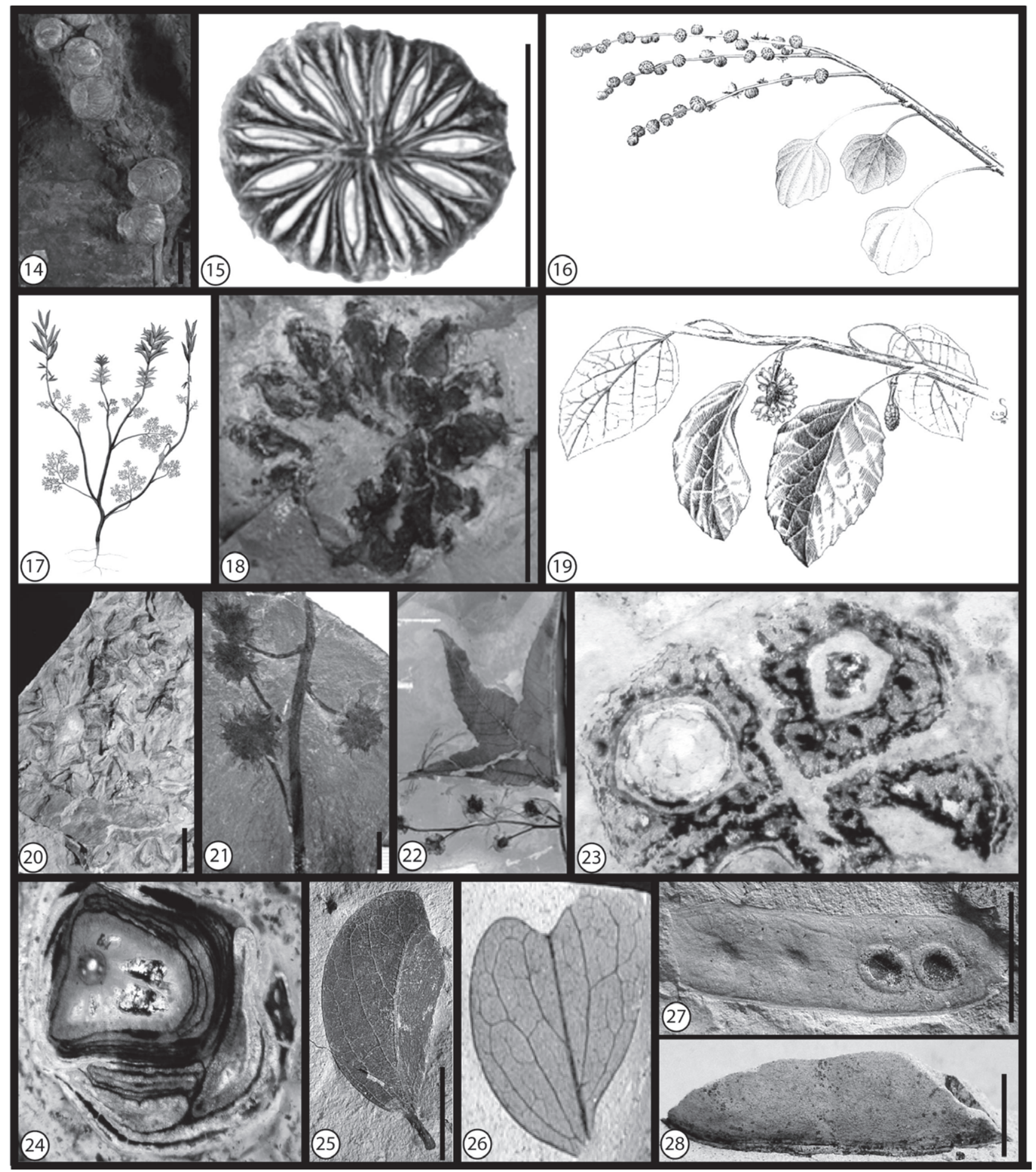

Figure 14) Nordenskioeldia borealis Heer, fruits attached to an axes. 15) Nordenskioeldia borealis Heer, cross section of a fruit. 16) "Nordenskioeldia plant" reconstruction. 17) Amersinia obtrullata Manchester, Crane et Golovneva, fruits from Big Flat Draw, Wyoming, USA. 18) Amersinia obtrullata Manchester, Crane et Golovneva, fruit from Joffre, Alberta, Canada. 19) Amersinia obtrullata Manchester, Crane et Golovneva, reconstruction by Clara Simpson. 20) Archaefructus Sun et al., reconstruction. 21) Macginicarpa, infructesences of the Clarno Plane. 22) Platanaceous material from the Green River Formation, Utah, courtesy of the Bruce Handley coll., UCMP. 23) Haloragaceae fruit from the Tarahumara Formation, Campanian of Sonora, Mexico. 24) Haloragaceae stem with attached leaves from the Tarahumara Formation, Campanian of Sonora, Mexico. 25) Pithecellobium leaf from the Oligocene Coatzingo Formation, Puebla, Mexico. 26) Stryphnodendron leaf from the Oligocene Coatzingo Formation, Puebla, Mexico. 27) Stryphnodendron fruit from the Oligocene Coatzingo Formation, Puebla, Mexico. 28) Pithecellobium fruit from the Oligocene Coatzingo Formation, Puebla, Mexico. 
Castillo and Cevallos-Ferriz (1999), which is most similar to plants growing naturally in New Zealand today (Figures 23-24). Among the Cenozoic plants known from the area, the legume family is turning out to have an interesting fossil record (Calvillo-Canadell and Cevallos-Ferriz, 2005). Plants that were expected to appear in the fossil record only in relatively later times have been demonstrated to be present much earlier, based on the association of leaves and fruits. For example, Inga is well documented from the Eocene La Carroza Formation, Nuevo León, and the Oligocene Coatzingo Formation, Puebla; Pithecellobium and Stryphnodendron are also known from the Coatzingo Formation (Figures 25-28), but recent studies also found leaflets of Pithecellobium in Miocene sediments of San Esteban Tizatlán, Tlaxcala, confirming the presence of the former in Central Mexico at least some 12 mya (CalvilloCanadell and Cevallos-Ferriz, 2005). The presence of vegetative and reproductive organs of Hymenaea in the Miocene amber of Simojovel de Allende, Chiapas, is another example of the wide distribution attained by Leguminosae, and of its past diversity during Cenozoic times in Mexico (Calvillo-Canadell and Cevallos-Ferriz, 2010).

\subsection{Final remarks}

Fossils represent an alternative to understand life, both present and past. The organisms that we find today as fossils lived on Earth prior to the appearance of mankind; as men keep discovering them, the interpretations of what they represent changes enormously. This in turn stimulates the imagination and encourages the production of more knowledge and the advancement of science.

In the last few decades, the interpretation of fossils - not only in plants - has become a challenge since their discussion goes beyond the idea of representing evidence of past life. They are the only direct source of information to interpret how past life existed and interacted, and are the greatest model to compare life historical moments, including the thoroughly studied extant life.Paleobotanical studies demonstrated that plants indeed changed through time. The definition of new groups and the understanding of their parts and organs produced impressive changes in plant concepts, as well as in the relationships among them, with other organisms, and with the environment.

It was certainly important to uncover that during the Carboniferous, ferns were not as diverse or abundant as suggested by the large amount of fronds and pinna present in the sediments. Even today it would be difficult to reconstruct a progymnopserm or a pteridosperm based only on the study of extant plants; even numerical analyses which may suggest the presence of these groups have been so far unable to assemble one. The reinterpretation of the fossil record of that time allowed a better understanding in different aspects of the reproductive biology of those plants and their impact in other plants that followed them.

Comparative plant biology uses similarity between isolated angiosperm fossil plant organs and those of their extant relatives; however, this may leave doubts on the identity of extinct plants. How different or similar could the whole plant be? Or could it be that the lineage had a large history with no or little changes? Reassembling flowering plants is producing spectacular results, similar to those attained through the study of Paleozoic and Mesozoic fossils. It has also allowed new ways to see the fossil plants, and continue to prove that they are the only source to give robust answers to biological inquires of past life. The presence of extinct angiosperm taxa, while expected from the interpretation of some of the isolated organs, is today well demonstrated as new taxa are being recognized from the various plant remains preserved as fossils. Early Cretaceous fossils of reproductive organs with few and numerous parts and attached to small herbaceous vegetative organs have been reconstructed as whole plants; their small size may explain in part the paucity of trees during this time, which became more common during the middle Cretaceous. Until the discovery of these early Cretacic plants, propositions of the phenotype of the earlier flowering plants were difficult to support. By the middle Cretaceous, isolated woods and leaves suggested the presence of plants related to Platanaceae or Trochodendraceae, but it was not until recently that reconstructions of whole plants enriched our understating of the plant biology of these groups during that time. With this fossil record it could be possible to confirm the presence of trees in the past, and now, through whole plant concepts generated after assembling the parts, it is clear that diversity change over time, as suggested by Platanaceae being more important during the Cretaceous and Paleogene than in more recent times.

Differences in reproductive biology from Cretaceous to more recent times have also been supported through plant reconstructions. Certainly Platanaceae is a great example of the evolution of processes related to different aspects of reproduction. For example, differences between the Clarno Plane (Eocene) and extant Platanus include perianth development, fruit indumentum, and pollen size, suggesting that the modern genus is more specialized for wind dispersal of fruits and pollen compared to the Eocene plant (Manchester, 1986). Similar changes in pollination syndrome have been postulated between Nordenskioldia and Trochodendron (Endress, 1989), where the absence of nectary scars in the fossil fruitlets suggests wind pollination in the earlier plants.

The use of reassembled fossil plants in phylogenetic and evolutionary studies has greater influence in the results than using their isolated parts. The literature is now overloaded of examples in which fossils are important to propose hypothesis on the origin and relationship of different taxa. Their use depends on the researchers and their discussion depends on how people interpret their presence in the fossil record. Simple, but self-explanatory examples are presented by Tiffney and Manchester (2001), and Manchester and Tiffney (2001) which suggested over a decade ago that the 
combination of data proceeding from extant and extinct taxa would resolve better any systematic question. In their discussion of Ulmaceae, biogeographic relationships comparing a cladogram based only on extant taxa and a second one containing an extinct one, Cedrelospermum, proofs that resolution improves when fossils are included.

Furthermore, whole plants are important to generate stronger hypothesis on the use of resources. For example, movement of water through the plant involves participation of several organs-like roots, stem or wood, and leaves. If we document plants that are similar to extant ones but differ in some aspects of their anatomy and/or morphology, their safe use of water is most likely different between closely related taxa. If it is as the examples discussed earlier suggest, Paleogene plants are represented by many extinct genera and Neogene plants correspond closer to extant genera, thus, it can be hypothesized that resources were utilized differently. The paucity of growth rings in Cretaceous and early Paleogene woods compared with Neogene ones suggests this change. As the reassembly of plants continues, physiological data will produce stronger hypothesis to explain plant-environment relationships.

\section{Conclusion}

In conclusion, the association of organs can help to make better taxonomic inferences because they provide a morphological tool about plants that grew in the past, and this improves the interpretation of evolutionary patterns of distribution and diversification as a source of historical information, directly through which may raise several questions that could be resolved with paleobotanical studies.

\section{References}

Ablaev, A.G.,Iljinskaja, L.A., 1982, Ulmus furcinervis (Borsuk) Ablaev, in, Takhtajan, A. (ed.), Magnoliophyta Fossilia URSS, 2. UlmaceaeBetulaceae: Nauka, Leningrad, 4-15.

APG III, 2009, An update of the Angiosperm Phylogeny Group classification for the orders and families of flowering plants: APG III: Botanical Journal of the Linnean Society, 161, 105-121.

Boucher, L.D., Manchester, S.R., Judd, W.S., 2003, An extinct genus of Salicaceae based on twigs with attached flowers, fruits, and foliage from the Eocene Green River Formation of Utah and Colorado, USA: American Journal of Botany, 90, 1389-1399.

Brown, R.W., 1929, Additions to the flora of the Green River formation: U.S. Geological Survey Professional Paper, 154-J, 279-292

Brown, R.W., 1934, The Recognizable Species of the Green River Flora: U. S. Geological Survey Professional Paper, 185-C.

Brown, R.W., 1946, Alterations in some fossil and living floras: Journal Washigton Academy Sciences, 36, 344-355.

Brown, R.W., 1962, Paleocene flora of the Rocky Mountains and Great Plains: U.S. Geological Survey Professional Paper, 375, 1-119.

Burnham, R.J., 1986, Foliar morphological analysis of the Ulmoideae (Ulmaceae) from the Early Tertiary of Western North America, Palaeontographica Abtteilung B Paleophytology, 201, 135-167.

Calvillo-Canadell, L.,Cevallos-Ferriz, S.R.S., 2005, Miocene Hymenaea flowers preserved in amber from Simojovel de Allende, Chiapas,
Mexico: Review of Palaeobotany and Palynology, 160, 126-134.

Calvillo-Canadell, L., Cevallos-Ferriz, S.R.S., 2010, Diverse assemblage of Eocene and Oligocene Leguminosae from Mexico: International Journal of Plant Sciences, 166, 671-692.

Chase, M.W., Zmarty, S., Ledó, M.D., Wurdack, K.J., Swensen, S.M., Fay, M.F., 2002, When in doubt, put it in Flacourtiaceae: a molecular phylogenetic analysis based on plastid rbcL DNA sequences: Kew Bulletin, 57, 141-181.

Cockerell, T.D.A., 1925, Plant and insect fossils from the Green River Eocene of Colorado: U. S. Natural Museum Procedures, 66, art. 19.

Crane, P.R., Friis, E.M., Pedersen, K. R., 1989, Reproductive structure and function in Cretaceous Chloranthaceae: Plant Systematycs and Evolution, 165, 211-226.

Crane, P.R., Manchester, S.R., Dilche, D.L., 1991, Reproductive and vegetative structure of Nordenskioldia (Trochodendraceae), a vesselless dicotyledon from the early Tertiary of the Northern Hemisphere: American Journal of Botany, 78 (10), 1311-1334.

Crane, P. R., Pedersen, K.R., Friis, E.M., Drinnan, A.N., 1993, Early Cretaceous (Early to Middle Albian) platanoid inflorescences associated with Sapindopsis leaves from the Potomac Group of Eastern North America: Systematic Botany, 18(2), 328-344.

Denk, F., Dillhoff, R.M., 2005, Ulmus leaves and fruits from the EarlyMiddle Eocene of northwestern North America: systematics and implications for caracter evolution in Ulmaceae: Canadian Journal of Botany, 3, 1663-1681.

Dilcher, D.L., Crane, P.R., 1984, Archaeanthus: an early angiosperm from the Cenomanian of the Western Interior of North America: Annals of the Missouri Botanical Garden, 71, 351-383.

Endress, P. K., 1989, Aspects of evolutionary differentiation of the Hamamelidaceae and the Lower Hamamelididae, Plant Systematics and Evolution, 162, 193-211.

Feng, G.P., Ablaev, A.G., Wang, Y.F., Li, C.S., 2003, Paleocene Wuyun flora in northeast China, Ulmus furcinervis of Ulmaceae, Acta Botanica Sinica, 54, 146-151.

Friis, E.M., Crane, P.R., Pedersen, K.R., 1988, Reproductive Structures of Cretaceous Platanaceae: Biologiske Skrifter Kongelige Danske Videnskabernes Selskab, 31, 1-55.

Friis, E.M., Crane, P.R., Pedersen, K.R., 2011, Early flowers and Angiosperm evolution: Cambridge, Cambridge University Press, $585 \mathrm{p}$.

Golovneva, L.B., 2008, ANew Platanaceous Genus Tasymia (Angiosperms) from the Turonian of Siberia: Paleontological Journal. 2.

Hernández-Castillo, G., Cevallos-Ferriz, S.R.S., 1999, Reproductive and vegetative organs with affinities to Haloragaceae from the Upper Cretaceous Huepac chert locality of Sonora, Mexico: American Journal of Botany 86(12), 1717-1734 .

Hickey, L. J., 1977, Stratigraphy and paleobotany of the Golden Valley Formation (early Tertiary) of western North Dakota: Colorado, Geological Society of America, 150, 181.

Hoffman, G. L., 1995, Paleobotany and paleoecology of the Joffre Bridge Roadcut locality (Paleocene), Red Deer, Alberta: Alberta, University of Alberta, Master thesis, $107 \mathrm{p}$.

Hollick, A., 1909, A new genus of fossil Fagaceae from Colorado: Torreya, 9, 1-3.

Judd, W.S., Campbell, C.S., Kellogg, E.A., Stevens, P.F., Donoghue, M.J.. 2002, Plant Systematics: a phylogenetic approach: Massachusetts, Sinauer, $464 \mathrm{p}$.

Knowlton, F.H., 1923, Fossil Plants from the Tertiary Lake Beds of Southcentral Colorado: U.S. Geological Survey Professional Paper 131-C.

Krassilov, V.A., 1975, Dirhopalostachyaceae - a new family of proangiosperms and its bearing on the problem of angiosperm ancestry: Palaeontographica B, 53, 100-110.

Kvaček, Z., 1995, Limnobiophyllum Krassilov—a fossil link between the Araceae and the Lemnaceae: Aquatic Botany, 50, 49-61.

Kvaček, Z., Manchester, S.R., Guo, S., 2001, Trifoliolate leaves of Platanus bella (Heer) comb. n. from the Paleocene of North America, Greenland, and Asia and their relationships among extinct and extant Platanaceae: International Journal of Plant Sciences, 162, 441-458. 
Kvaček, Z., Manchester, S.R., 2004, Vegetative and reproductive structures of the extinct Platanus neptuni from the Tertiary of Europe and relationships within the Platanaceae: Plant Systematics And Evolution, 244,1-29.

Kvaček, Z., Manum, S.B., Boulter, M.C., 1984, Angiosperms from the Paleogene of Spitzbergen, including an unfinished work by A.G. Nathorst: Palaeontographica Abteilung B, 232, 103-128.

Kvaček Z., 2008, Whole-plant reconstructions in fossil angiosperm research: International Journal of Plant Sciences, 169 (7), 918-927.

Landolt, E., 1986, The family of Lemnaceae-a monographic study: Zurich, Veröffentlichungen der Geobotanischen Institutes der ETH, Stiftung Ruibel, $71 \mathrm{p}$.

Lesquereux, L., 1872, An enumeration with descriptions of some Tertiary fossil plants from specimens procured in the explorations of Dr. F.v. Bayden in 1870: Geological Survey of the Territories; Annual report of the United States Geological Survey of the Territories, 5 (Suppl), $22 \mathrm{p}$.

Lesquereux, L., 1878, Contributions to the fossil floras of the Western Territories, Part II, The Tertiary Flora: Bulletin of the United States Geological and Geographical Survey of the Territories, 7, $366 \mathrm{p}$.

Lott, T.A, Manchester, R.A., Dilcher, D.L., 1998, A unique and complete polemoniaceous plant from the middle Eocene of Utah, USA: Review in Palaeobotany and Palynology, 104, 39-49.

Lott, M.S., Volin, J.C., Pemberton, R.W., Austin, D.F., 2003, The reproductive biology of the invasive ferns Lygodium microphyllum and $L$. japonicum (Schizaeaceae): implications for invasive potential: American Journal of Botany, 90, 1144-1152.

MacGinitie, H.D., 1941, A middle Eocene flora from the central Sierra Nevada: Contributions to Paleontology, Carnegie Institution of Washington, 543, $178 \mathrm{p}$.

MacGinitie, H.D., 1953, Fossil plants of the Florissant beds, Colorado: Contributions to Paleontology, Carnegie Institution of Whashington, $599,198 \mathrm{p}$.

MacGinitie, H.D., 1969, The Eocene Green RIver flora of northestern Colorado and northeastern Utah: Berkeley, University of California Press, $83,140 \mathrm{p}$.

MacGinitie, H.D., 1974, An early middle Eocene flora from the Yellowstone-Absaroka volcanic Province, northwestem Wind River Basin, Wyoming: Berkeley, University of California Press, $108,103 \mathrm{p}$.

Magallón-Puebla, S., Herendeen, P.S., Crane, P.R., 1997, Quadriplatanus georgianus gen. et sp. nov.: Staminate and Pistillate Platanaceous Flowers from the Late Cretaceous (Coniacian-Santonian) of Georgia, USA: International Journal of Plant Sciences, 158 (3), 373-394.

Manchester, S. R., 1986, Vegetative and Reproductive Morphology of an Extinct Plane Tree (Platanaceae) from the Eocene of Western North America: Botanical Gazette, 147, 200-226.

Manchester, S.R., 1989a, Attached reproductive and vegetative remains of the extinct American-European genus Cedrelospermum (Ulmaceae) from the Early Tertiary of Utah and Colorado: American Journal of Botany, 76, 256-276.

Manchester, S.R., 1989b, Systematic and fossil history of the Ulmaceae, in Crane, P.R., Blackmore, S. (eds.), Evolution, systematics and fossil history of Hamamelidae, 2: Oxford, UK., 221-251.

Manchester, S.R., 2001, Leaves and Fruits of Aesculus (Sapindales) from the Paleocene of North America: International Journal of Plant Sciences, 162, 985-998.

Manchester, S.R., Crane, P.R., 1983 Attached leaves, inflorescences, and fruits of Fagopsis, an extinct genus of fagaceous affinity from the Oligocene Florissant Flora of Colorado, USA: American Journal of Botany, 70, 1147-1164.

Manchester, S.R., Tiffney, B.H., 2001, Integration of paleobotanical and neobotanical data in the assessment of phylogeographic history of Holarctic angiosperm clades: International Journal of Plant Sciences, 162, S19-S27.

Manchester, S.R., Dilcher, D.L., Wing, S.L., 1998, Attached leaves and fruits of myrtaceous affinity from the Middle Eocene of Colorado: Review of Paleobotany and Palynology, 102, 153-163.
Manchester, S. R., Judd, W.S., Handley, B., 2006, Foliage and fruits of early poplars (Salicaceae: Populus) from the Eocene of Utah, Colorado, and Wyoming: International Journal of Plant Sciences, 167, 897-908.

Manos, P.S., Soltis, P.S., Douglas, E.S., Manchester, S.R., Sang-Hun Oh, Bell, C.D., Dilcher, D.L., Stone, D.E., 2007, Phylogeny of Extant and Fossil Juglandaceae Inferred from the Integration of Molecular and Morphological Data Sets: Systematic Biology, 56 (3), 412-430.

Maslova, N.P., 2008, Association of vegetative and reproductive organs of platanoids (Angiospermae): significance for systematics and phylogeny: Paleoecological Journal, 42 (12), 1393-1404.

Mclver, E.E., Bassinger, J.F., 1993, Flora of the Ravenscrag Formation (Paleocene), Southwestern Saskatchewan, Canada: Palaeontographica Canadiana, 10, 1-85.

McIver, E.E., Basinger, J.F., 1999, Early Tertiary floral evolution in the Canadian high artic: Annals of the Missouri Botanical Garden, 86, 523-545.

Mindell, R.A., Stockey, R.A., Beardt, G., 2006, Anatomically Preserved Staminate Inflorescences of Gynoplatananthus oysterbayensis gen. et sp. nov. (Platanaceae) and associated Pistillate fructifications from the Eocene of Vancouver Island, British Columbia: International Journal of Plant Sciences, 167 (3), 591-600.

Newberry, J.S., 1868, Notes on the later extinct floras of North America, with descriptions of some new species of fossil plants from the Cretaceous and Tertiary strata. Part 2. The Tertiary flora of North America: Annals of the Lyceum of Natural History of New York, 9, 27-76.

Newberry, J.S., 1898, The later extinct floras of North America: Washington, US Geological Survey Monograph 35, $295 \mathrm{p}$.

Pedersen, K.R., Friis, E.M., Crane, P.R., Drinnan, A.N., 1994, Reproductive structures of an extinct platanoid from the Early Cretaceous (latest Albian) of eastern North America: Review of Palaeobotany and Palynology, 80, 291-303.

Pigg, K. B., Stockey, R.A., 1991, Platanaceous plants from the Paleocene of Alberta, Canada: Review of Palaeobotany and Palynology, 70, 125-146.

Pigg, K.B., Stockey, R.A., Maxwell, S.L., 1992, Paleomyrtinaea. A new genus of permineralized fruits and seeds from the Eocene of British Columbia and Paleocene of North Dakota?: Canadian Journal of Botany, 71, 1-9.

Schweitzer, H.J., 1977, Die räto-jurassischen Floren des Iran und Afganistan. 4. Die rätische Zwitterblüte Irania hermaphroditica nov. spec. und ihre Bedeutung für die phylogenie der Angiospermen: Palaeontographica B, 161, 98:145.

Shipunov, A.B., Sokoloff, D.D., 2003, Schweitzeria, a new name for Irania Schweitzer (Fossil Gymnospermae): Bulletin Moscow Society of Naturalists, 108, 89-90.

Soepadmo, E., 1977, Ulmaceae: Flora Malesiana Series I, 8, 31-36.

Soltis, D.E., Soltis P.S., Chase, M.W., Endress P.K., 2005, Phylogeny, evolution, and classification of flowering plants: Massachusetts, Sinauer, 370.Stockey, R.A., Hoffman, G.L., Rothwell, G.W., 1997, The fossil monocot Limnobiophyllum scutatum: resolving the phylogeny of Lemnaceae: American Journal of Botany, 84, 355-368.

Stockey, R.A., Hoffman, G.L., Rothwell, G.W., 1997, The fossil monocot Limnobiophyllum scutatum: resolving the phylogeny of Lemnaceae: American Journal of Botany, 84, 355-368.

Tanai, T., Wolfe, J.A., 1977, Revisions of Ulmus and Zelkova in the middle and late Tertiary of western North America: U.S. Geological Survey Proffesional Paper No. 1026, 26 p.

Tiffney, B.H., Manchester, S.R., 2001, The use of geological and paleontological evidence in evaluating plant phylogeographic hypotheses in the Northern Hemisphere Tertiary: International Journal of Plant Sciences, 162, S3-S17.

Zhou, Z.H., Barret, P.M., Hilton, J., 2003, An exceptionally preserved lower Cretaceous ecosystem: Nature, 421, 807-814.

Manuscript received: February 10, 2013.

Corrected manuscript received: April 10, 2013.

Manuscript accepted: September 25, 2013. 